\title{
Immunophenotypic characterization of human bone marrow mast cells. A flow cytometric study of normal and pathological bone marrow samples*
}

\author{
Luis Escribano ${ }^{\mathrm{a}}$, Alberto Orfao ${ }^{\mathrm{b}, * *}$, Jesús Villarrubia ${ }^{\mathrm{a}}$, Beatriz Díaz-Agustín ${ }^{\mathrm{a}}$, \\ Carlos Cerveróa, Agustín Rios ${ }^{\mathrm{c}}$, José L. Velasco ${ }^{\mathrm{a}}$, Juana Ciudad ${ }^{\mathrm{b}}$, José L. Navarro ${ }^{\mathrm{a}}$ and \\ Jesús F. San Miguel ${ }^{\mathrm{c}}$ \\ ${ }^{a}$ Servicio de Hematología, Hospital Ramón y Cajal, Universidad de Alcalá de Henares, Madrid, \\ Spain \\ ${ }^{\mathrm{b}}$ Servicio Central de Citometría and ${ }^{\mathrm{c}}$ Departamento de Medicina, Servicio de Hematología, \\ Universidad de Salamanca, Spain
}

Received 7 February 1997

Revised 27 January 1998

Accepted 26 February 1998

\begin{abstract}
The goal of the present paper was to define the immunophenotype of bone marrow mast cells (BMMC) from healthy controls and patients with hematologic malignancies (HM) based on the use of multiple stainings with monoclonal antibodies analyzed by flow cytometry. Our results show that BMMC from both groups of individuals display a similar but heterogenous immunophenotype. The overall numbers of BMMC are higher in the HM group of individuals $(p=0.08)$. Three patterns of antigen expression were detected: (1) markers constantly positive in all cases analyzed (CD9, CD29, CD33, CD43, CD44, CD49d, CD49e, CD51, CD71, CD117, and FceRI), (2) antigens that were constantly negative (CD1a, CD2, CD3, CD5, CD6, CD11a, CD14, CD15, CD16, CD19, CD20, CD21, CD23, CD25, CD30, CD34, CD38, CD41a, CD42b, CD65, CD66b, HLA-DR, and CD138), and (3) markers that were positive in a variable proportion of cases - CD11b (50\%), CD11c (77\%), CD13 (40\%), CD18 (20\%), CD22 (68\%), CD35 (27\%), CD40 (67\%), CD54 (88\%) and CD61 (40\%). In addition, BMMC from all cases explored were $\mathrm{CD} 45^{+}$, and this antigen was expressed at an intensity similar to that of mature granulocytes.

In summary, our results show that BMMC from both healthy controls and HM patients display a relatively heterogenous immunophenotype. Interestingly, we have observed clear differences between the immunophenotype of BMMC and MC from other tissues. This could be due either to the heterogeneity of human MC according to their tissue localization or to the sensitivity of the method used for antigen detection.
\end{abstract}

Keywords: Mast cells, immunophenotype, bone marrow, flow cytometry

\footnotetext{
${ }^{*}$ Supported by a grant from the Fondo de Investigaciones Sanitarias de la Seguridad Social (FIS 95/0768) and Fundación Jesus Gangoiti. B. Díaz-Agustín is the recipient of the Grant FIS 95/0768.

${ }^{* *}$ Corresponding author: Alberto Orfao, Servicio Central de Citometría, Hospital Clínico Universitario, Paseo de San Vicente s/n, 37007 Salamanca, Spain. Fax: +34 23264743.
} 


\section{Introduction}

Mast cells (MC) are long-living cells derived from precursors which originate in the bone marrow [27-29]. $\mathrm{MC}$ have been grown in vitro from $\mathrm{CD} 34^{+}$precursors from bone marrow, cord blood and peripheral blood mononuclear cells $[3,10,19,26,28]$. Heterogeneity is a characteristic of MC, which may exhibit variable morphological and phenotypical characteristics [4-7,12,17-20,40].

The immunophenotype of human MC has been studied in different organs such as the uterus [21], lung [43,45], skin [34,43], heart [41], ascites [43], and gastrointestinal tract [43]. Due to their low frequency, enrichment of MC has been a prerequisite for their immunophenotypical analysis. For this purpose, both tissue disgregation using enzymatic methods $[41,44]$ and procedures to purify the cell fraction containing MC, have been extensively used [44]. While the former techniques have been shown to affect the detection of several MC antigens [41,44], the procedures used for MC enrichment such as sedimentation and centrifugation may induce selective cell loss [44]. These studies have shown that among other markers, MC express two highly characteristic cell surface receptors: the high affinity IgE binding sites (Fc\&RI) [11,15,22-25,33] and the MC growth factor (MGF) receptor or stem cell factor (SCF) receptor (CD117) [14,21,31,41,43]. Information on the immunophenotype of human BMMC is currently scanty and its analysis has only been performed in BM from patients suffering from chronic myeloid leukemia [43,45] or mast cell leukemia [9,38]. No extensive information has been provided so far on the characteristics of MC from normal human bone marrow.

Recently, we have shown that BMMC, although present at very low frequencies in normal BM, can be identified and enumerated using multiparametric flow cytometry [35]. This would allow the phenotypic characterization of human BMMC in a systematic way. The aim of the present paper is to define the immunophenotype of human BMMC from both normal individuals and patients diagnosed from different hematological malignancies (HM), in which $\mathrm{MC}$ apparently are not part of the malignant clone, using a large panel of monoclonal antibodies (MoAbs) analyzed at flow cytometry. In addition, results on the reactivity obtained for each of the markers analyzed were expressed as the molecule equivalent of soluble fluorochrome (MESF) which makes them comparable in future studies using the same monoclonal antibody conjugates.

\section{Material and methods}

BM samples. BM was obtained after informed consent from 44 subjects: 15 healthy volunteers undergoing either orthopedic surgery or bone marrow harvest and 29 patients diagnosed as chronic lymphoproliferative disorders - 13 B-cell chronic lymphocytic leukemia (B-CLL) cases, 4 B-cell non-Hodgkin lymphomas (B-NHL), 3 Waldenström's macroglobulinemia (WM), 4 multiple myeloma (MM), and 5 monoclonal gammopathy of undetermined significance (MGUS).

All samples were collected in $\mathrm{K}_{3}$-EDTA anticoagulant and immediately diluted $1 / 1$ ( $\left.\mathrm{vol} / \mathrm{vol}\right)$ in phosphate-buffered saline (PBS). After collection, the sample was passed several times through a $25 \mathrm{~mm}$ gauge needle in order to disgregate the bone marrow particles and adjusted to a concentration of $7.5 \times 10^{9}$ nucleated cells/l.

Immunological marker analysis. BM samples were analyzed by direct immunofluorescence using triple- and double-staining combinations of monoclonal antibodies directly conjugated with fluorescein isothiocyanate (FITC), phycoerythrin (PE), and either the PE-cyanin 5 (PE-Cy5) fluorochrome tandem or PerCP. In all cases antibodies were used at saturation concentrations. The following monoclonal 
antibody conjugates were used: (1) $10 \mu \mathrm{l}$ of FITC-conjugated CD2, CD3, CD5, CD13, CD14, CD15, CD19, CD20, CD22, CD25, CD33, CD34, CD44, CD71, anti-HLA-DR (purchased from BectonDickinson, San José, CA, USA), CD40 (Cymbus Biosciences, Ltd., Southampton, UK), CD38, CD65, (Caltag Laboratories, San Francisco, CA, USA), CD11a, CD11b, CD11c, CD35, CD54, CD66b (CLB, Amsterdam, The Netherlands), CD29 (Coulter Corporation, Miami, FL, USA), CD21, CD30, CD42b, CD61 (Dakopatts, Copenhagen, Denmark), CD41a (Immunotech, Marseille, France), CD18, CD45, CD51 (Menarini Diagnostics, Barcelona, Spain), CD117 (Nichirei Corporation, Tokyo, Japan), CD6 (Centro de Inmunología Molecular, La Habana, Cuba), CD9, CD43, CD49d, CD49e (Serotec, UK) anti-IgE (The Binding Site, Birmingham, UK), and CD138 (Immunoquality Products, Gröningen, The Netherlands); (2) $10 \mu \mathrm{l}$ of PE-conjugated CD13, CD16, CD23, CD33, CD38 (purchased from BectonDickinson), CD1a (Cymbus Biosciences, Ltd.), and CD117 (Immunotech and Nichirei Corporation); and (3) $5 \mu \mathrm{l}$ of PE/Cy5-conjugated CD13, CD14, CD33, CD34, CD38, CD45 (Caltag Laboratories), or $10 \mu \mathrm{l}$ of PerCP-conjugated CD45 (Becton-Dickinson)

Briefly, 200- $\mu$ l of a sample containing aproximately $1.5 \times 10^{6}$ nucleated cells were incubated for $10 \mathrm{~min}$ at room temperature with the MoAb mentioned above. Afterwards, erythrocytes were lysed by incubating cells for $10 \mathrm{~min}$ (room temperature) with $2 \mathrm{ml} /$ tube of FACS lysing solution (BectonDickinson). Isotype-matched mouse non-specific immunoglobulins and a tube stained for CD117-PE were used as negative and positive controls, respectively. For the MC localization, the following panel of MoAb combinations (FITC/PE/PE-Cy5 or PerCP) was constantly used: CD34/CD117/CD45, CD138/CD117/CD38, and anti-IgE/CD117/CD33. Data acquisition was performed on a FACScan flow cytometer (Becton-Dickinson) using the LYSYS II software program (Becton-Dickinson) for at least 10,000 events/tube. In addition, a second acquisition step, through a SSC/CD117 live gate, was performed to increase the sensitivity of the method for the analysis of MC present at a low frequency [35]. For data analysis, the Paint-A-Gate Plus software (Becton-Dickinson) was used. The quantitation of positivity for each of the markers tested was performed using QuickCal beads (Flow Cytometry Standards Corporation, San Juan, Puerto Rico), and results were expressed as the mean number of molecules equivalent of soluble fluorochrome (MESF) obtained specifically for the MC. The threshold for positivity was 5,000 MESF for FITC and 500 MESF for PE.

Statistical methods. Mean values and their standard deviations were calculated for all variables in each group of samples. The Mann-Whitney $U$-test was used in order to assess the statistical significance of the differences observed between groups of individuals.

\section{Results}

In all $\mathrm{BM}$ samples analyzed, $\mathrm{MC}$ were clearly identified based on their strong CD117 expression and in spite of their low frequency. BMMC displayed a typical FSC/SSC pattern similar to that of normal mature monocytes. The mean number of BMMC was $0.029 \pm 0.038 \%$ and it was significantly $(p=0.08)$ higher in patients with HM as compared to normal controls $(0.018 \pm 0.023 \%)$ versus $0.034 \pm 0.043 \%)$.

The immunophenotypical characteristics of BMMC are shown in Fig. 1 and Table 1. As may be seen, three patterns of antigen expression were detected: (1) markers constantly positive in all cases analyzed (CD9, CD29, CD33, CD43, CD44, CD45, CD49d, CD49e, CD51, CD71, CD117, and FceRI), (2) antigens that were constantly negative (CD1a, CD2, CD3, CD5, CD6, CD11a, CD14, CD15, CD16, CD19, CD20, CD21, CD23, CD25, CD30, CD34, CD38, CD41a, CD42b, CD65, CD66b, HLA-DR, 

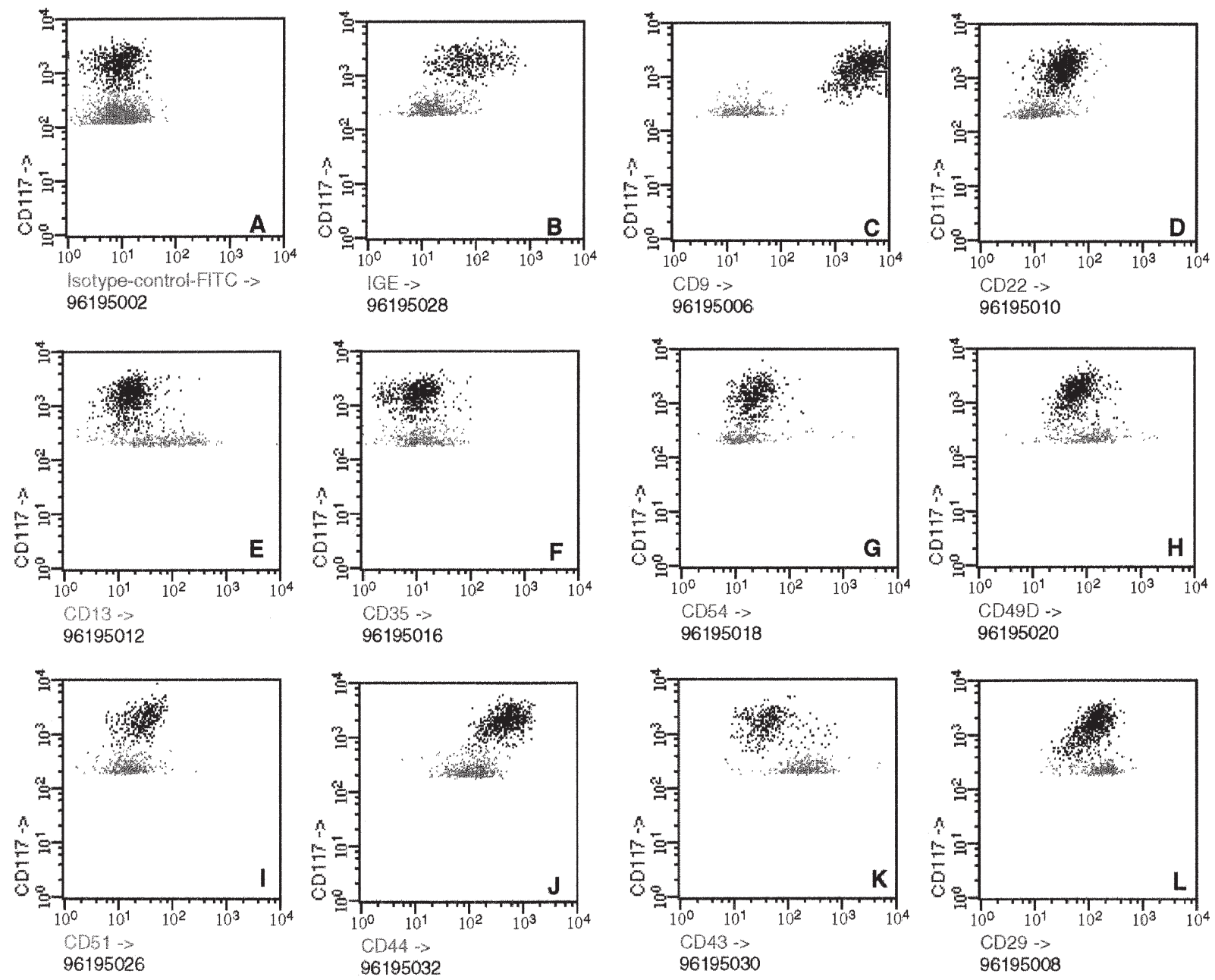

Fig. 1. Representative dot plots (A-L) of the immunophenotypic analysis of bone marrow mast cells (black dots) once selected on the basis of a high expression of CD117. MESF values $\left(\times 10^{3}\right)$ were as follows: IgE, 40.0 (B); CD9, 134.4 (C); CD22, 9.9 (D); CD13, 4.5 (E); CD35, 2.7 (F); CD54, 6.3 (G); CD49d, 19.1 (H); CD51, 8.3 (I); CD44, 163.3 (J); CD43, $12.5(\mathrm{~K})$; CD29, $39.7(\mathrm{~L})$.

and CD138), and (3) markers that were positive in a variable proportion of cases - CD11b (50\%), CD11c (77\%), CD13 (40\%), CD18 (20\%), CD22 (68\%), CD35 (27\%), CD40 (67\%), CD54 (88\%) and CD61 (40\%). In addition, among those antigens that were constantly positive three groups could be identified according to their intensity of antigen expression: (1) strong positive $(>12,000$ and $>50,000$ MESF for FITC and PE, respectively) - CD9, CD11c, CD29, CD44, CD49d, CD117 and FceRI, (2) dim positive (from 5,000 to 19,000 MESF of FITC) - CD49e, CD51, CD54, and CD71, and (3) antigens showing a variable intensity of expression (from 5,000 to 51,000 MESF of FITC) CD33 and CD43. Those antigens showing a variable expression for the different cases analyzed such as CD11b, CD13, CD18, CD22, CD35, CD40, and CD61, were expressed at a low intensity $(<12,000$ MESF) when positive; the relative distribution of positive and negative cases as well as the range of antigen expression are shown in Table 1. In addition, BMMC from all cases explored were $\mathrm{CD}^{4} 5^{+}$, this antigen was expressed at an intensity similar to that of mature granulocytes. 
Table 1

Immunophenotypic characteristics of bone marrow mast cells in healthy controls and patients with hematological malignancies

\begin{tabular}{|c|c|c|}
\hline $\mathrm{CD}$ & Controls & Hematological malignancies \\
\hline 9 & $\begin{array}{c}945.8 \pm 165.8 \\
780.0-1111.7 \\
(100 \%)\end{array}$ & $\begin{array}{c}1837.1 \pm 373.7 \\
523.9-2727.5 \\
(100 \%)\end{array}$ \\
\hline $11 b$ & $\begin{array}{l}<5.0 \\
(0 \%)\end{array}$ & $\begin{array}{c}5.6 \pm 0.2 \\
<5.0-6.0 \\
(76 \%)\end{array}$ \\
\hline $11 \mathrm{c}$ & $\begin{array}{c}11.6 \pm 2.4 \\
<5.0-14.0 \\
(66.6 \%)\end{array}$ & $\begin{array}{c}17.7 \pm 5.8 \\
5.1-22.5 \\
(87.5 \%)\end{array}$ \\
\hline 13 & $\begin{array}{c}7.5 \pm 1.8 \\
<5.0-9.3 \\
(67 \%)\end{array}$ & $\begin{array}{c}6.5 \pm 0.7 \\
<5.0-7.9 \\
(34 \%)\end{array}$ \\
\hline 18 & $\begin{array}{c}5.6 \pm 0.5 \\
<5.0-6.1 \\
(33 \%)\end{array}$ & $\begin{array}{l}<5.0 \\
(0 \%)\end{array}$ \\
\hline 22 & $\begin{array}{c}6.4 \pm 0.5 \\
<5.0-7.9 \\
(50 \%)\end{array}$ & $\begin{array}{c}7.0 \pm 0.5 \\
<5.0-9.9 \\
(78.5 \%)\end{array}$ \\
\hline 29 & $\begin{array}{c}39.7 \pm 5.7 \\
34.0-45.5 \\
(100 \%)\end{array}$ & $\begin{array}{c}34.3 \pm 4.3 \\
15.1-62.7 \\
(100 \%)\end{array}$ \\
\hline 33 & $\begin{array}{c}22.7 \pm 6.2 \\
7.8-51.7 \\
(100 \%)\end{array}$ & $\begin{array}{c}19.4 \pm 2.6 \\
5.8-33.8 \\
(100 \%)\end{array}$ \\
\hline 35 & $\begin{array}{l}<5.0 \\
(0 \%)\end{array}$ & $\begin{array}{l}7.0 \pm 0.7 \\
<5.0-9.0 \\
(33.3 \%)\end{array}$ \\
\hline 40 & NA & $\begin{array}{c}9.0 \pm 3.3 \\
<5.0-12.3 \\
\quad(67 \%)\end{array}$ \\
\hline 43 & $\begin{array}{c}38.7 \pm 22.4 \\
11.4-83.2 \\
(100 \%)\end{array}$ & $\begin{array}{c}17.7 \pm 3.1 \\
7.9-30.5 \\
(100 \%)\end{array}$ \\
\hline 44 & $\begin{array}{c}185.9 \pm 43.8 \\
82.1-339.2 \\
(100 \%)\end{array}$ & $\begin{array}{c}177.2 \pm 33.0 \\
56.9-296.6 \\
(100 \%)\end{array}$ \\
\hline $45^{*}$ & $(100 \%)$ & $(100 \%)$ \\
\hline $49 d$ & $\begin{array}{c}18.4 \pm 0.7 \\
16.9-19.2 \\
(100 \%)\end{array}$ & $\begin{array}{c}18.1 \pm 2.8 \\
12.1-25.9 \\
(100 \%)\end{array}$ \\
\hline $49 \mathrm{e}$ & $\begin{array}{c}7.1 \pm 1.1 \\
5.0-8.9 \\
(100 \%)\end{array}$ & $\begin{array}{c}7.6 \pm 1.3 \\
5.0-14.5 \\
(100 \%)\end{array}$ \\
\hline 51 & $\begin{array}{c}8.6 \pm 2.3 \\
5.6-13.2 \\
(100 \%)\end{array}$ & $\begin{array}{c}8.4 \pm 0.8 \\
5.4-12.8 \\
(100 \%)\end{array}$ \\
\hline
\end{tabular}


Table 1

(Continued)

\begin{tabular}{ccc}
\hline CD & Controls & Hematological malignancies \\
\hline 54 & $14.2 \pm 2.4$ & $9.3 \pm 1.7$ \\
& $<5.0-18.7$ & $5.0-18.6$ \\
& $(75 \%)$ & $(100 \%)$ \\
61 & $11.3 \pm 0.5$ & $7.8 \pm 1.6$ \\
& $<5.0-11.8$ & $<5.0-7801$ \\
71 & $(66 \%)$ & $(50 \%)$ \\
& $5.7 \pm 0.4$ & $6.4 \pm 1.3$ \\
& $5.0-6.5$ & $(100 \%)$ \\
$117^{* *}$ & $(100 \%)$ & $293.5 \pm 124.6$ \\
& $303.9 \pm 52.7$ & $94.8-645.6$ \\
& $87.8-860.1$ & $(100 \%)$ \\
FC $\varepsilon \mathrm{RI}$ & $(100 \%)$ & $171.7 \pm 39.2$ \\
& $428.3 \pm 140.1$ & $41.2-463.0$ \\
& $288.1-568.5$ & $(100 \%)$ \\
& $(100 \%)$ &
\end{tabular}

Results expressed as mean + SD range of MESF $\left(\times 10^{3}\right)$. In brackets, percentage of positivie cases. ${ }^{*} \mathrm{PE} / \mathrm{Cy} 5$ or PerCP and ${ }^{* *} \mathrm{PE}$-conjugated monoclonal antibodies. NA, not analyzed.

After comparing the immunophenotype of BMMC from healthy subjects and patients suffering from $\mathrm{HM}$, no significant differences were observed between both groups of individuals for any of the markers explored, regarding both the incidence of positivity and their fluorescence intensity. Nevertheless, it could be noted that a slightly higher mean expression of CD43, CD54, CD61, and Fc $\varepsilon$ RI was evident among normal BMMC controls. In contrast, expression of both CD9 and CD11c was slightly higher for the BMMC from patients with HM.

\section{Discussion}

The immunophenotype of human MC has long been hampered by their low frequency and the need to use $\mathrm{MC}$ enrichment procedures prior to their phenotypic analysis. This could contribute to the increased variability of the results obtained. We have recently shown [35] that multiparametric flow cytometry is a useful tool for the identification and enumeration of human $\mathrm{MC}$ on whole $\mathrm{BM}$ erythrocyte-lysed samples which obviates sample manipulation prior to the analysis of the immunophenotype of BMMC. Accordingly, BMMC could be easily identified on the basis of their strong reactivity to the CD117 and FceRI antigens $[2,8,37,39]$ in the absence of expression for the CD138, CD34 and CD38 markers [35].

At present, it is well established that MC belong to the myeloid lineage $[1,26,27,29,30]$. Thus, MC are expected to express myeloid-associated antigens. In the present study, it is shown that BMMC do constantly express CD33 in variable amounts. Moreover, in most of the individuals analyzed BMMC were $\mathrm{CD} 13^{+}$, although the expression of this antigen was weaker than that observed for CD33. In contrast, the CD14, CD15, CD16, CD65 and CD66b myeloid-associated markers were found to be constantly negative in the BMMC from all the individuals studied. These findings are, to a large extent, in agreement with previous reports on the immunophenotypical characteristics of human MC from other tissues different from BM [21,41-45]. However, interestingly, CD13 has been reported to be negative in MC from all tissues analyzed [41-44]. The weak intensity of CD13 expression may 
account for this discrepancy. The selection of sensitive fluorochromes, such as phycoerythrin, is of particular relevance for its detection. In this sense, it should be noted that this is the first study in which the phenotype of human BMMC is extensively analyzed in a large group of individuals using flow cytometry, and this technique has shown to be a much more sensitive approach for the detection of surface antigens than conventional immunochemistry [36]. In relation to myeloid antigens, another finding of this study that has not been previously reported, is the lack of expression of the CD66b antigen on BMMC.

Lymphoid-associated markers have been reported as absent in normal human MC [21,41-45], although the CD2 expression, alone or together with CD22, has been found in a case of mast cell leukemia [9] and in a patient suffering from SMCD [13], respectively. In the present study, BMMC from a high proportion of the individuals analyzed showed reactivity for the B-cell-associated CD22 antigen. Interestingly, BMMC from B-CLL patients constantly displayed reactivity for this antigen which was found in variable proportions in normal samples, suggesting predominance of this subset of BMMC in these individuals. The absence of CD2 in all samples analyzed indicates that the finding of BMMC expressing the CD2 antigen should be considered as an aberrant phenotype [13]. In our experience, other lymphoid related markers were constantly negative.

In the present study, we have also explored the expression of activation-related markers as well as cell adhesion molecules. Regarding activation markers, CD25, CD30 and the HLA-DR antigens were found to be absent in BMMC in all the cases studied. In contrast, reactivity to the transferrinreceptor (CD71) was constantly present. Interestingly, CD71 has been reported to be negative in human MC from different tissues [43-45], while controversial results have been obtained regarding the CD25 expression which has been described as positive or negative in lung and intestinal MC [32], and constantly negative in the uterus, skin and ascitic fluid $[42,43,45]$. Once again, the reactivity found in the present study for the CD71 antigen was relatively dim, suggesting that the use of sensitive techniques, such as flow cytometry immunophenotyping and PE-conjugates, is essential for its detection. On the other hand, CD25 was constantly negative, indicating that expression of this antigen could be either specific for MC from tissues other than the BM or related to the MC activation state. CD35 expression, which has been previously described as negative in several tissues $[16,41$, $42,44,45]$, was weakly expressed in BMMC from $27 \%$ of the cases studied. Regarding cell adhesion molecules, all the cases studied were positive for CD11c, CD29, CD43, CD44, CD49d, CD49e, CD51, and CD54. In addition, CD11b, CD18, and CD61 expression was variable, while CD11a, $\mathrm{CD} 41 \mathrm{a}$, and CD42b were constantly negative. In general, these results confirm previous findings on the immunophenotype of human $\mathrm{MC}$ except for $\mathrm{CD} 11 \mathrm{c}$ which in almost all tissues analyzed has been reported as negative [41-45]. Interestingly, we have recently shown that BMMC from a patient suffering from an aggresive form of systemic mast cell disease were CD41a negative while this antigen was clearly positive on the peripheral blood MC from the same patient [38]. Regarding CD18 expression, discrepant results have been reported since MC from the lung, ascitic fluid, skin, and intestinal mucosa $[42,43,45]$ have been described as CD18 negative, while MC from the uterus have been reported to be $\mathrm{CD} 18$ positive [21]. In the present study, both $\mathrm{CD} 18^{+}$and $\mathrm{CD} 18^{-}$cases were observed, suggesting that CD18 expression by BMMC may vary from one individual to another.

Upon comparing the BMMC from healthy subjects and patients suffering from HM, it was observed that the mean number of BMMC was significantly higher in the latter group as compared to normal subjects. However, from the immunophenotypical point of view, no significant differences were detected between both groups of individuals for any of the markers explored. These results indicate that, although increased numbers of BMMC can be detected in patients diagnosed with different 
haematological malignancies, these cells are reactive since, from the phenotypical point of view, they were identical to normal human BMMC.

In summary, our results show that BMMC from both healthy controls and HM patients display a relatively heterogeneous immunophenotype. Interestingly, we have observed clear differences between the immunophenotype of BMMC and MC from other tissues. This could be due either to the heterogeneity of human MC according to their tissue localization or to the sensitivity of the method used for antigen detection.

\section{References}

[1] H. Agis, M. Willheim, W.R. Sperr, A. Wilfing, E. Krömer, E. Kabrna, E. Spanblöchl, H. Strobl, K. Geissler, A. Spittler, G. Boltz-Nitulescu, O. Majdic, K. Lechner and P. Valent, Monocytes do not make mast cells when cultured in the presence of SCF: Characterization of the circulating mast cell progenitor as a c-kit ${ }^{+}, \mathrm{CD} 34^{+}, \mathrm{Ly}^{-}, \mathrm{CD}_{4}{ }^{-}, \mathrm{CD}_{17}^{-}$, colony-forming cell, J. Immunol. 151 (1993), 4221-4227.

[2] L.K. Ashman, A.C. Cambareri, L.B. To, R.J. Levinsky and C.A. Juttner, Expression of the YB5.B8 antigen (c-kit proto-oncogene product) in normal human bone marrow, Blood 78 (1991), 30-37.

[3] R.I. Ashman, D.L. Jarboe, D.H. Conrad and T.F. Huff, The mast cell-committed progenitor: In vitro generation of committed progenitors from bone marrow, J. Immunol. 146 (1991), 211-216.

[4] A.G. Becker, F.K. Chung, D.M. McDonald, S.C. Lazarus, O.L. Frick and W.M. Gold, Cutaneous mast cell heterogeneity: response to antigen in atopic dogs, J. Allergy Clin. Immunol. 78 (1986), 937-942.

[5] A.D. Befus, J. Bienenstock and J.A. Denburg, Mast cell differentiation and heterogeneity, Immunol. Today 6 (1985), $281-284$.

[6] A.D. Befus, T. Lee, T. Goto, R. Goodacre, F. Shanahan and J. Bienenstock, Mast cell differentiation and heterogeneity, in: Histologic and Functional Properties of Mast Cells in Rats and Humans, A.D. Befus, J. Bienenstock and J.A. Denburg, eds, Raven Press, New York, 1986, pp. 205-213.

[7] J. Bienenstock, A.D. Befus, F. Pearce, J.A. Denburg and R. Goodacre, Mast cell heterogeneity: derivation and function with emphasis on the intestine, J. Allergy Clin. Immunol. 70 (1982), 407-412.

[8] H.J. Buhring, A. Ullrich, K. Schaudt, C.A. Muller and F.W. Busch, The product of the proto-oncogene c-kit is a human bone marrow surface antigen of hemopoietic precursor cell which is expressed on a subset of acute non-lymphoblastic leukemic cells, Leukemia 5 (1991), 854-860.

[9] R. Dalton, L. Chan, E. Batten and S. Eridani, Mast cell leukaemia: evidence for bone marrow origin of the pathological clone, Br. J. Haematol. 64 (1986), 397-406.

[10] J.A. Denburg, M. Richardson, S. Telizyn and J. Bienenstock, Basophil/mast cell precursors in human peripheral blood, Blood 61 (1983), 775-780.

[11] A.M. Dvorak, E.S. Schulman, S.P. Peters, D.W. MacGlashan, H.H. Newball, R.P. Schleimer and L.M. Lichtenstein, Immunoglobulin E-mediated degranulation of isolated human lung mast cells, Lab. Invest. 53 (1985), 45-56.

[12] L. Enerbäck, Mast cell differentiation and heterogeneity, in: Mast Cell Heterogeneity: The Evolution of the Concept of a Specific Mucosal Mast Cell, A.D. Befus, J. Bienenstock and J.A. Denburg, eds, Raven Press, New York, 1986, pp. 1-26.

[13] L. Escribano, A. Orfao, J. Villarrubia, C. Cerveró, J.L. Velasco, F. Martin, J.F. San Miguel and J.L. Navarro, Expression of lymphoid-associated antigens in mast cells: Report of a case of systemic mast cell disease, Br. J. Haematol. 91 (1995), 941-943.

[14] M. Födinger, G. Fritsch, K. Winkler, W. Emminger, G. Mitterbauer, H. Gadner, P. Valent and C. Mannhalter, Origin of human mast cells: Development from transplanted hematopoietic stem cells after allogeneic bone marrow transplantation, Blood 84 (1994), 2954-2959.

[15] A. Froese, Receptors for IgE on mast cells and basophils, Prog. Allergy 34 (1984), 142-187.

[16] W. Füreder, H. Agis, M. Willheim, H.C. Bankl, U. Maier, K. Kishi, M.R. Müller, K. Czerwenka, T. Radaszkiewicz, J.H. Butterfield, G.W. Klappacher, W.R. Sperr, M. Oppermann, K. Lechner and P. Valent, Differential expression of complement receptors on human basophils and mast cells - Evidence for mast cell heterogeneity and CD88/C5aR expression on skin mast cells, J. Immunol. 155 (1995), 3152-3160.

[17] S.J. Galli, Mast cell differentiation and heterogeneity, in: Mast Cell Heterogeneity: Can Variation in Mast Cell Phenotype be Explained Without Postulating the Existence of Distinct Mast Cell Lineages, A.D. Befus, J. Bienenstock and J.A. Denburg, eds, Raven Press, New York, 1986, pp. 167-181.

[18] S.J. Galli, New approaches for the analysis of mast cell maturation, heterogeneity, and function, Fed. Proc. 46 (1987), 1906-1914. 
[19] S.J. Galli, New insights into "the riddle of the mast cells": Microenvironmental regulation of mast cell development and phenotypic heterogeneity, Lab. Invest. 62 (1990), 5-33.

[20] S.J. Galli, A.M. Dvorak and H.F. Dvorak, Basophils and mast cells: morphologic insights into their biology, secretory patterns, and function, Prog. Allergy 34 (1984), 1-141.

[21] C.-B. Guo, A. Kagey-Sobotka, L.M. Lichtenstein and B.S. Bochner, Immunophenotyping and functional analysis of purified human uterine mast cells, Blood 79 (1992), 708-712.

[22] B. Helm, P. Marsh, D. Vercelli, E. Padlan, H. Gould and R. Geha, The mast cell binding site on human immunoglobulin E, Nature 331 (1988), 180-183.

[23] K. Ishizaka and T. Ishizaka, Cellular, molecular and clinical aspects of allergic disorders, in: Immunoglobulin E. Byosinthesis and Immunological Mechanism of IgE-mediated Hypersensitivity, L. Gupta and M. Good, eds, Plenum Press, New York, 1979, pp. 153-178.

[24] T. Ishizaka, Analysis of triggering events in mast cells for immunoglobulin E-mediated histamine release, J. Allergy Clin. Immunol. 67 (1981), 90-96.

[25] T. Ishizaka and K. Ishizaka, Activation of mast cells for mediator release through IgE receptors, Prog. Allergy 34 (1984), 188-235.

[26] A.S. Kirshenbaum, S.W. Kessler, J.P. Goff and D.D. Metcalfe, Demonstration of the origin of human mast cells from CD34 ${ }^{+}$bone marrow progenitor cells, J. Immunol. 146 (1991), 1410-1415.

[27] Y. Kitamura, S. Go and K. Hatanaka, Decrease of mast cells in $\mathrm{W} / \mathrm{W}^{\mathrm{V}}$ mice and their increase by bone marrow transplantation, Blood 52 (1978), 447-452.

[28] Y. Kitamura, K. Hatanaka, M. Murakami and H. Shibata, Presence of mast cells precursors in peripheral blood of mice demonstrated by parabiosis, Blood 53 (1979), 1085-1088.

[29] Y. Kitamura, M. Shimada, K. Hatanaka and Y. Miyano, Development of mast cells from grafted bone marrow cells in irradiated mice, Nature 268 (1977), 442-443.

[30] Y. Kitamura, M. Yokoyama, H. Matsuda and T. Ohno, Spleen colony forming cell as a common precursor for tissue mast cells and granulocytes, Nature 291 (1981), 159-160.

[31] F. Lanza, S. Moretti, S. Papa, F. Malavasi and G. Castoldi, Report on the Fifth International Workshop on Human Leukocyte Differentiation Antigens, Boston, November 3-7, 1993, Haematologica 79 (1994), 374-386.

[32] N. Maggiano, F. Colotta, F. Castellino, R. Ricci, S. Valitutti, L.M. Larocca and P. Musiani, Interleukin-2 receptor expression in human mast cells and basophils, Int. Arch. Allergy Appl. Immunol. 91 (1990), 8-14.

[33] H. Metzger, The high affinity receptor for IgE on mast cells, Clin. Exp. Allergy 21 (1991), 269-279.

[34] G. Mirowski, K.F. Austen, L. Chiang, R.F. Horan, A.L. Sheffer, N. Weidner and G.F. Murphy, Characterization of cellular dermal infiltrates in human cutaneous mastocytosis, Lab. Invest. 63 (1990), 52-62.

[35] A. Orfao, L. Escribano, J. Villarrubia, J.L. Velasco, C. Cerveró, J. Ciudad, J.L. Navarro and J.F. San Miguel, Flow cytometric analysis of mast cells from normal and pathological human bone marrow samples. Identification and enumeration, Am. J. Pathol. 149 (1996), 1493-1499.

[36] A. Orfao, A. Ruiz-Arguelles, F. Lacombe, K. Ault, G. Basso and M. Danova, Flow cytometry: Its applications in hematology, Haematologica 80 (1995), 69-81.

[37] T. Papayannopoulou, M. Bice, V.C. Broudy and K.M. Zsebo, Isolation of c-kit receptor expressing cells from bone marrow, peripheral blood, and fetal liver: functional properties and composite antigenic profile, Blood 78 (1991), $1403-1412$.

[38] A. Radbruch and D. Recktenwald, Detection and isolation of rare cells, Curr. Opin. Immunol. 7 (1995), $270-273$.

[39] M.Z. Ratajezac, S.M. Luger and A.M. Gewirtz, The c-kit proto-oncogene in normal and malignant human hematopoiesis, Int. J. Cell Cloning 10 (1992), 205-214.

[40] E.S. Schulman, R.B. Pollack, T.J. Post and S.P. Peters, Histochemical heterogeneity of dispersed human lung mast cells, J. Immunol. 144 (1990), 4195-4201.

[41] W.R. Sperr, H.C. Bankl, G. Mundigler, G. Klappacher, K. Grossschmidt, H. Agis, P. Simon, P. Laufer, M. Imhof, T. Radaszkiewicz, D. Glogar, K. Lechner and P. Valent, The human cardiac mast cell: Localization, isolation, phenotype, and functional characterization, Blood 84 (1994), 3876-3884.

[42] P. Valent, The phenotype of human eosinophils, basophils, and mast cells, J. Allergy Clin. Immunol. 94(Suppl.) (1994), $1177-1183$.

[43] P. Valent, L.K. Ashman, W. Hinterberger, F. Eckersberger, O. Majdic, K. Lechner and P. Bettelheim, Mast cell typing: Demonstration of a distinct hematopoietic cell type and evidence for immunophenotypic relationship to mononuclear phagocytes, Blood 73 (1989), 1778-1785.

[44] P. Valent and P. Bettelheim, Cell surface structures on human basophils and mast cells: Biochemical and functional characterization, Adv. Immunol. 52 (1992), 333-423.

[45] P. Valent, O. Majdic, D. Maurer, M. Bodger, M. Muhm and P. Bettelheim, Further characterization of surface membrane structures expressed on human basophils and mast cells, Int. Arch. Allergy Appl. Immunol. 91 (1990), 198-203. 


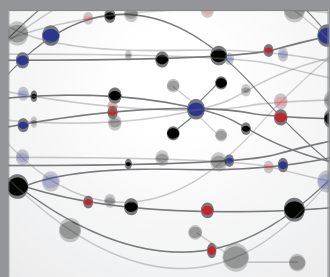

The Scientific World Journal
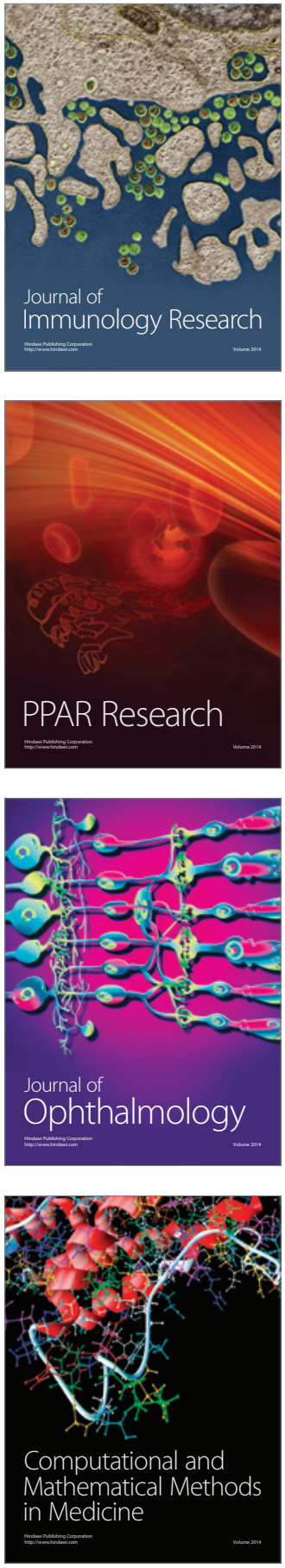

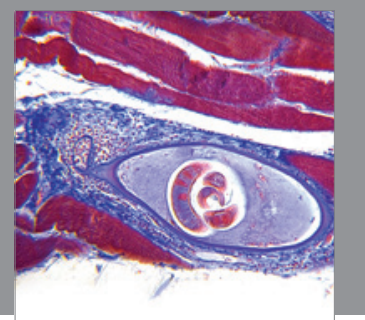

Gastroenterology

Research and Practice
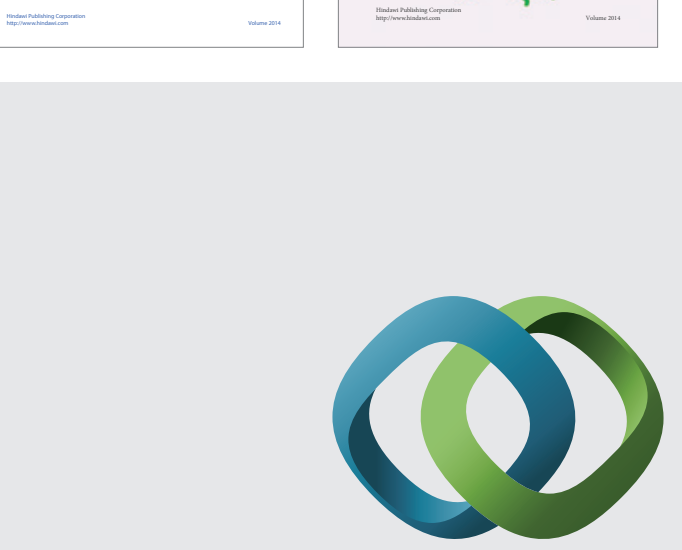

\section{Hindawi}

Submit your manuscripts at

http://www.hindawi.com


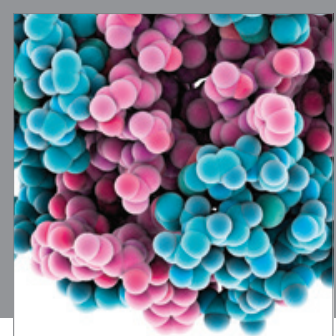

Journal of
Diabetes Research

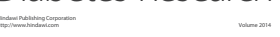

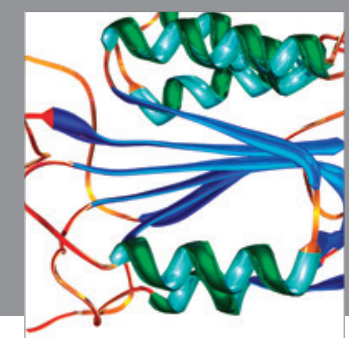

Disease Markers
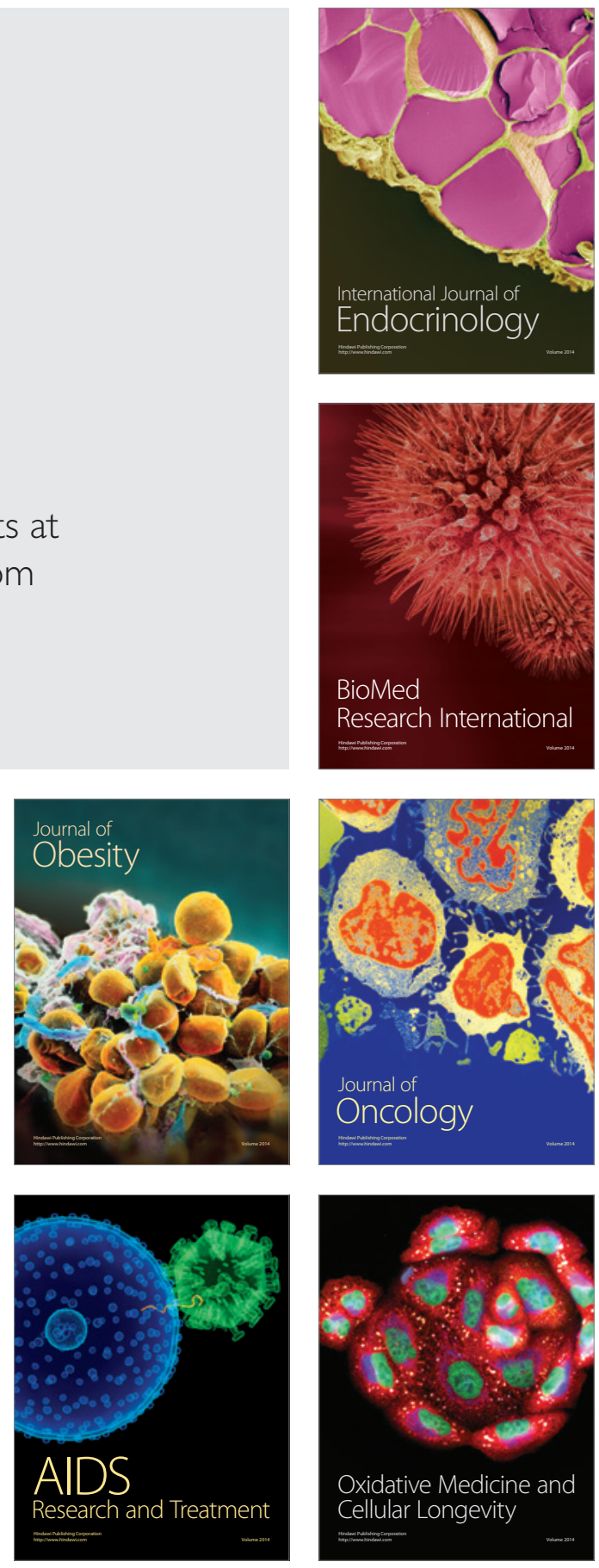